\title{
The teaching of health promotion and interprofessional education as a learning tool in undergratuated courses: a documentary analysis
}

\author{
O ensino da promoção da saúde e a educação interprofissional como ferramenta de \\ aprendizagem em cursos de graduação: uma análise documental
}

\author{
Kleber Jessivaldo Gomes das Chagas ${ }^{1}$, Johny Everson Gonçalves ${ }^{1}$, Gabriella Seixas Sampaio \\ Saraiva $^{1}$, Gabriela Lisboa ${ }^{1}$, Ana Cláudia Camargo Gonçalves Germani ${ }^{2}$
}

\begin{abstract}
Chagas KJG, Gonçalves JE, Saraiva GSS, Lisboa G, Germani ACCG. The teaching of health promotion and interprofessional education as a learning tool in undergratuated courses: a documentary analysis / O ensino da promoção da saúde e a educação interprofissional como ferramenta de aprendizagem em cursos de graduação: uma análise documental. Rev Med (São Paulo). 2020 Jan-Feb;99(1):96-101.
\end{abstract}

\begin{abstract}
Given the integrality of the health-disease-care process, and the importance of health promotion in this context, the training of future health professionals must include the development of abilities that allow a full therapeutic plan centered on the patient. In order to achieve this goal, there are some initiatives being employed in several countries that aim to offer a better formation for their health care professionals, capacitating them in offering a more integral care, based on collaborative practices. Objective: To verify the teaching of skills and abilities listed in CompHP in some of the health care courses in USP, and to compare the use of Interprofessional Education as a polishing tool in these students' training with the HPAC Guide. Method: Preliminary exploratory qualitative study based on the documental analysis of the pedagogical-political-project (PPP) and the description of disciplines in eight courses in USP-SP, comparing them with guidelines from CompHP and HPAC.
\end{abstract}

Keywords: Health promotion; Health persopnnel/educaton; Interprofessional education.
RESUMO: Frente à integralidade do processo saúde-doençacuidado e a importância da promoção da saúde nesse contexto, a formação dos futuros profissionais da saúde deve ter o desenvolvimento de habilidades que permitam um cuidado integral centrado no paciente. Para isto, existem algumas iniciativas utilizadas por diversos países para fornecer uma melhor formação para seus profissionais no intuito de capacitálos para oferecer um cuidado mais integral pautado na prática colaborativa. Objetivo: analisar a presença das competências e domínios presentes no CompHP em alguns cursos da saúde da USP e comparar a utilização da Educação Interprofissional como ferramenta de aprimoramento da formação dos estudantes desse curso com o Guia da HPAC. Método: Estudo qualitativo exploratório preliminar estruturado a partir da análise documental do projeto político pedagógico (PPP) e ementa de disciplinas de oito cursos da USP-SP e comparação com Guidelines do CompHP e do HPAC.

Descritores: Promoção da saúde; Pessoal de saúde/educação; Educação interprofissional.

$1^{\circ}$ Classified Panels Awards - Medical Education - Scientific Awards of the XXXVIII COMU 2019 - Congresso Médico Universitário da FMUSP, São Paulo, SP, 4-6 Oct 2019.

1. Faculdade de Medicina FMUSP, Universidade de São Paulo. ORCID: Chagas KJG - https://orcid.org/0000-0002-0667-5688; Gonçalves JE - https://orcid.org/0000-0002-2749-3736; Saraiva GSS - https://orcid.org/0000-0002-2626-3875; Lisboa G - https://orcid.org/00000001-5900-0564.Email: kleber.chagas@fm.usp.br, gabriela.lisboa@fm.usp.br, gabriella.seixas@fm.usp.br,j.goncalves@fm.usp.br 2. Departamento de Medicina Preventiva, Faculdade de Medicina FMUSP, Universidade de São Paulo. https://orcid.org/0000-00027409-915X. Email: ana.germani@fm.usp.br.

Endereço para correspondência: Kleber Jessivaldo Gomes das Chagas. Rua França Pinto, 133. Apto 52. Vila Mariana. São Paulo, SP. CEP: 04016030. 


\section{INTRODUCTION} Ealth promotion is seen internationally as
an key element for an effective health care system. In Brazil, the National Health Care Policy (Política Nacional de Promoção à Saúde - PNPS) aims to "promote equality and improvement in living conditions, widening the potential for individual and collective health and reducing vulnerabilities and health hazards resulting from social, economic, political, cultural and environmental determinants". Thus, given the wide scope of health promotion, we initially have to review some concepts that are essential to our analysis.

According to the Ottawa Charter, Health Promotion

is:

"the process of enabling people to increase control over, and to improve, their health. To reach a state of complete physical, mental and social well-being, an individual or group must be able to identify and to realize aspirations, to satisfy needs, and to change or cope with the environment. Health is, therefore, seen as a resource for everyday life, not the objective of living. Health is a positive concept emphasizing social and personal resources, as well as physical capacities. Therefore, health promotion is not just the responsibility of the health sector, but goes beyond healthy life-styles to well-being" (p.19)2.

Another important concept is Intersectoral Collaboration, which is "the possibility of the possibility of content/form interpenetration between disciplines and universally produced knowledge. In fact, interdisciplinarity brings the interpenetration of the areas, allowing a dialogue between "knowledge" (p.165) to understand the problem, make decisions and execute the proposals inherent to the fields involved. The theme can be studied by various areas of knowledge that integrate various contents, from the centralization of the whole".

Another relevant point is Interprofessional Education, which "occurs when students from two or more professions learn about each other, from each other, and to each other to enable effective collaboration and improve health outcomes" (p.7). Thus, the subject both educates and is educated, which leads to the development of collaborative interprofessional practice. This, in turn, "happens when multiple health workers from different professional backgrounds work together with patients, families, carers and communities to deliver the highest quality of care. It allows health workers to engage any individual whose skills can help achieve local health goals" $(\mathrm{p} .7)^{4}$.

Given these concepts, we should remember that ideas about health promotion in Brazil were introduced in the mid-1980s, fueled by the debate on health reform. The discussion of these ideas was highlighted at the 8th National Health Conference (CNS) in 1986, which had as its theme "Democracy is Health" and constituted a forum to fight for the decentralization of the health system and the implementation of social policies that defended and take care of life (National Health Conference, 1986). It was a key moment in the movement of the Brazilian Sanitary Reform and the affirmation of the inseparability between the guarantee of health as an irrevocable social right and the guarantee of other human rights and citizenship 5 .

In 2019, in the United States, the Guidance on Developing Quality Interprofessional Education for the Health Professions was prepared. It was developed by the Health Interprofessional Accreditors Collaborative and the National Center for Interprofessional Practice and Education to facilitate the preparation of health professions students for collaborative interprofessional practice and to provide a guide for institutions to develop, implement and evaluate systematic approaches. in Interprofessional Education - EIP and programs focused on this type of approach $^{6}$.

The CompHP, Developing Competencies and Professional Standards for Health Promotion Capacity Building in Europe, is an initiative that, considering the interdisciplinarity, intersectoriality and complexity of the expanded concept of health requires, rethinks the skills needed for Health Promotion. This initiative started in 2009 and involved 24 European countries and was presented by the Pan-European Project of the European Workshop of the International Union for Health Promotion and Education (UIPES). The skills listed are similar to those applied in other countries (Australia, Canada, New Zealand and the United Kingdom) in the areas of health education and public health. Thus, the CompHP lists the guiding basic knowledge and proposes nine areas of competence: 1 . Possibility of change, 2. Advocacy for health, 3. Mediation through partnerships, 4. Communication, 5. Leadership, 6. Diagnosis, 7. Planning, 8. Implementation, 9. Evaluation and research ${ }^{7}$.

The National Curriculum Guidelines (NCG) of undergraduate health courses reaffirm the importance of such professionals having a "generalist, humanist, critical and reflective" education and placing health promotion as a spectrum of expected actions. In these NGCs we can find the appreciation of the development of skills that allow interprofessional learning and collaborative work also interprofessional, to offer effective and integral care ${ }^{8}$.

In this context, the questions arise: At USP, do health courses provide health promotion education aligned with international recommendations? Are there teaching methods based on interprofessional education being used? If so, which ones?

With this in mind, a documental analysis was made in order to evaluate how interprofessional education is being used in the process of training health professionals at USP. With the results of this study, we compared health promotion teaching in some health courses 
with international guidelines such as the Guidance on Developing Quality Interprofessional Education for the Health Professions and CompHP ${ }^{9}$.

\section{GOALS}

To make a comparative analysis of the methods used to promote health promotion education at USP with international guides on health promotion and IPE.

\section{METHODOLOGY}

The documental analysis of the 2018 Pedagogical Political Projects (PPP) and course syllabus of eight courses listed in Table 1 were compared to the Guidance on Developing Quality Interprofessional Education for the Health Profession and the COmpHP

Comparison of PPP competencies and menu content with the list of ten basic knowledge guiding health promotion core competencies and where possible locating one or more CompHP domains, listed below:

1. Health promotion concepts, principles and ethical values as defined in the Ottawa Charter (WHO, 1986) and subsequent letters and statements;

2. Concepts of equity in health, social justice and health as a human right as a basis for action in health promotion;

3. The determinants of health and their implications for health promotion actions;

4. The impact of social and cultural diversity on health and health inequities and their implications for health promotion actions;

5. Health promotion models and approaches that support empowerment, participation, partnerships and equality as the basis of health promotion actions;

6. Current theories and evidence that underpin effective leadership, advocacy and partnership building and their implications for health promotion actions;

7. Current models and approaches to effective project and program management (including needs diagnosis, planning, implementation and evaluation) and their application in health promotion actions;

8. The basic evidence and research methods, including qualitative and quantitative methods, required to inform and evaluate health promotion actions;

9. The communication processes and current information technology necessary for the effectiveness of health promotion action;

10. The systems, policies and legislations that impact health and their relevance to health promotion ${ }^{10}$.

Comparison with guidance from the faculty guide on the four characteristics of HPAC's quality EPI plans (justification, results-based goals, deliberate design, and student and subject assessment) within and across the programs listed next:

1.Values / Ethics for Interprofessional Practice: Working with individuals from other professions and maintaining a climate of mutual respect and shared values.

2. Roles / Responsibilities: Use knowledge of one's job and other professions to adequately assess and address patients' health care needs and to promote and improve the health of populations.

3.Interprofessional Communication: Communicating with patients, families, communities, health professionals and other fields responsibly and responsibly that supports a team approach to health promotion and maintenance, and disease prevention and treatment.

4. Teams and Teamwork: Apply team dynamics relationship building principles and values to effectively perform in different team roles to plan, deliver, and evaluate population-centered care / health and health programs and policies. That are safe, timely and efficient, effective and equitable ${ }^{11}$.

The Ethical Guidelines for Research in Humanities and Social Sciences contained in Resolution 510/2016 were adopted for the development of this research, therefore for using public domain information there was no registration or evaluation by the CEP/CONEP system ${ }^{12}$.

\section{RESULTS}

In Table 1, we can see how this theme is inserted in the analyzed documents.

In the selected subjects (Table 2), it is observed that among the 4 strategies of interprofessional education - Values/ethics for interprofessional practice, roles/ responsibilities, Interprofessional Communication, Teams and Work Teams - are used in only some of the disciplines that addressed the theme of health promotion.

Given that both the CompHP and the guide developed by HPAC make interprofessional education essential for the training of good health professionals who have the skills necessary for collaborative interprofessional practice, it is essential to create an enabling environment for the development of health. IPE, giving the students of these eight courses the possibility to experience IPE during their graduation, aiming to achieve a more complete formation and a better qualification to work in multiprofessional teams, thus providing a more integral and effective care. When evaluating the semesters of health promotion related disciplines, we saw that, being concentrated between the second and fourth semester, they could be used to provide an enabling environment for the implementation of Interprofessional Education, having their insertion in the core curricula of these courses. 
Chagas KJG, et al. The teaching of health promotion and interprofessional education as a learning tool.

Table 1. Competencies located in menus and PPPs according to CompHP domains, 2019

\begin{tabular}{|c|c|c|}
\hline Major & Basic guiding concept & Domain \\
\hline PE & $\begin{array}{l}\text { PPP Concept 1: Professionals should be able to use Sport } \\
\text { as a means to empower the population to improve their } \\
\text { quality of life. } \\
\text { Concepts } 3 \text { and } 7 \text { in discipline HSP } 0153 \text { - Fundamentals of } \\
\text { Public Health in Physical Education and Sport: } \\
\text { - Identify object and objectives of Public Health as an area } \\
\text { of knowledge and field of intervention; } \\
\text { - Recognize basic aspects of the relationship between health } \\
\text { and society, population patterns of disease and disease } \\
\text { distribution and characteristics of each society's response } \\
\text { to problems. }\end{array}$ & $\begin{array}{l}\text { Planning, Implementation and Evaluation (Excerpt from } \\
\text { subject): } \\
\text { Relate to the Physical Education and Sports professions focusing } \\
\text { on Program Planning, Execution and Evaluation } \\
\text { Research (Excerpt from PPP): Students of the EEFE-USP } \\
\begin{array}{l}\text { Bachelor Degree in Physical Education are offered participation } \\
\text { in different areas of research }\end{array}\end{array}$ \\
\hline Nursing & $\begin{array}{l}\text { The Concepts } 1 \text { to } 5,7 \text { and } 8 \text { are contained in the competencies } \\
\text { to be developed by the professional contained in the PPP. } \\
\text { In addition, we have several disciplines that focus on the } \\
\text { development of health promotion skills, such as: } \\
\text { - } 0701211 \text { - Primary Care Nursing and Child, Woman and } \\
\text { Mental Health; } \\
\text { - ENS0237 - Primary Care Nursing and Adult and Elderly } \\
\text { Health; } \\
\text { - ENS0236 - Fundamentals of public health and nursing care; } \\
\text { - ENS0425 - Communicable Disease Nursing focusing on } \\
\text { Collective Health. }\end{array}$ & $\begin{array}{l}\text { The set of disciplines listed and the PPP aim for a health } \\
\text { promotion approach in which we can find the following domains: } \\
\text { - Partnership mediation; } \\
\text { - Communication; } \\
\text { - Leadership; } \\
\text { - Diagnosis; } \\
\text { - Planning; } \\
\text { - Implementation; } \\
\text { - Search }{ }^{14} \text {. }\end{array}$ \\
\hline Physiotherapy & $\begin{array}{l}\text { Concept } 3 \text { and 10: in MFT0878 - Health and Citizenship I: } \\
\text { Experience of the health system panorama in Brazil and the } \\
\text { techno-care model organization, as well as Health Indicators } \\
\text { and determinants }\end{array}$ & $\begin{array}{l}\text { mediation (excerpt from PPP): Acting multiprofessionally and } \\
\text { interdisciplinarily at the various levels of health care in health } \\
\text { programs aimed at promoting, } \\
\text { Research }^{15} \text {. }\end{array}$ \\
\hline Speech therapy & $\begin{array}{l}\text { Guiding basic concepts } 1-5,9 \text {, and } 10 \text { can be found in the } \\
\text { specific course objectives listed in the PPP. } \\
\text { We also found several disciplines that address health } \\
\text { promotion: } \\
\text { - MFT0747 Scientific Methodology Applied to Health } \\
\text { Promotion; } \\
\text { - MFT0351 Speech Therapy from the Health Promotion } \\
\text { Perspective; } \\
\text { - MFT0323 Health Promotion Research and Practice } \\
\text { - MFT0918 Advanced Health Promotion Research and } \\
\text { Practice; } \\
\text { - MFT0763 Introduction to the Speech Therapy Clinic in } \\
\text { Health Promotion. }\end{array}$ & $\begin{array}{l}\text { Nas ementas das disciplinas listadas ao lado e no PPP do curso } \\
\text { podemos encontrar os seguintes domínios: In the syllabus of the } \\
\text { subjects listed beside and in the PPP of the course we can find } \\
\text { the following domains: } \\
\text { - Diagnosis; } \\
\text { - Planning; } \\
\text { - Implementation; } \\
\text { - Research }{ }^{16} \text {. }\end{array}$ \\
\hline Medicine & $\begin{array}{l}\text { We can find the } 10 \text { guiding basic concepts in PPP and in the } \\
\text { menus of some subjects. However, some of the concepts }(1 \text {, } \\
2,3,4 \text { and 5) are addressed with greater emphasis than others. } \\
\text { The disciplines in which we can locate such concepts are: } \\
\text { - MSP1010 - Introduction to Medicine and Health; } \\
\text { - MSP1041 - Health-Disease-Care Process I; } \\
\text { - MSP } 1043 \text { - Health-Disease-Care Process III. }\end{array}$ & $\begin{array}{l}\text { Due to the recent formulation of the Medical Course Curriculum } \\
\text { and the new Curriculum having a more focused approach to } \\
\text { international educational trends, we can locate several domains: } \\
\text { - Mediation; } \\
\text { - Communication; } \\
\text { - Diagnosis; } \\
\text { - Leadership; } \\
\text { - Planning; } \\
\text { - Implementation; } \\
\text { - Research }\end{array}$ \\
\hline Nutrition & $\begin{array}{l}\text { The FSP nutrition course has been reformulated and with it } \\
\text { the PPP provides for training based on a broader concept of } \\
\text { health promotion. Thus, in the PPP of this course we can find } \\
\text { all the guiding concepts, enabling a very solid formation in } \\
\text { the theme of health promotion. In addition, we have several } \\
\text { subjects in which such concepts are inserted, such as: } \\
\text { - HSP0284 - Health Promotion; } \\
\text { - PST2072 - Prevention and Health Promotion in the field } \\
\text { of Sexuality II; } \\
\text { - HNT0221 - Public Food and Nutrition Policies. }\end{array}$ & $\begin{array}{l}\text { In the PPP of this course we can find the following domains: } \\
\text { - Mediation; } \\
\text { - Diagnosis; } \\
\text { - Planning; } \\
\text { - Implementation; } \\
\text { - Research; } \\
\text { - Leadership }\end{array}$ \\
\hline Dentistry & $\begin{array}{l}\text { In PPP, we have the concepts 1, 2, } 3 \text { and } 10 . \text { These can also } \\
\text { be found in the subjects: } \\
\text { - ODS0700 - Extended Health Promotion Clinic; } \\
\text { - ODS0705 - Collective Health in Dentistry; } \\
\text { - ODO0501 - Preventive Orthondontics; } \\
\text { - ODO0105 - Prevention in Pediatric Dentistry Clinic. }\end{array}$ & $\begin{array}{l}\text { The following domains are found in PPP: } \\
\text { - Communication; } \\
\text { - Diagnosis; } \\
\text { - Planning; } \\
\text { - Implementation; } \\
\text { - Search }{ }^{19} \text {. }\end{array}$ \\
\hline $\begin{array}{l}\text { Occupational } \\
\text { Therapy }\end{array}$ & $\begin{array}{l}\text { Concepts } 1-5 \text { are present in the list of competencies listed } \\
\text { in the PPP. }\end{array}$ & $\begin{array}{l}\text { Communication (excerpts from MFT0710): } \\
\text { "Establish a critical relationship with the concept of language } \\
\text { - inscribed in the list of human activities with attributed } \\
\text { importance for communication - relate some of its forms of } \\
\text { expression, and the elements that constitute its processes" } 20\end{array}$ \\
\hline
\end{tabular}


Table 2. Description of Interprofessional education approach in selected subjects in the eight courses reviewed

\begin{tabular}{l|l|c|l}
\hline Course & Discipline & Semester & Strategy \\
\hline PE & $\begin{array}{l}\text { HSP0153 - Health Essentials } \\
\text { Education in Physical Education } \\
\text { and Sport }\end{array}$ & $2^{\circ}$ & Not mentioned \\
\hline Nursing & $\begin{array}{l}\text { 07001255 - Interprofessional Health } \\
\text { Practices, Training and Education }\end{array}$ & $3^{\circ}$ & $\begin{array}{l}\text { Values / Ethics for Interprofessional Practice, } \\
\text { Roles / Responsibilities, Interprofessional } \\
\text { Communication, Teams and Work Teams. }\end{array}$ \\
\hline Physiotherapy & MFT0878 - Health and Citizenship I & $3^{\circ}$ & Not mentioned \\
\hline Speech therapy & $\begin{array}{l}\text { MFT0351 - Speech Therapy in } \\
\text { Health Promotion Perspective }\end{array}$ & $4^{\circ}$ & $\begin{array}{l}\text { Roles/responsibilities, Interprofessional } \\
\text { Communication }\end{array}$ \\
\hline Nutrition & $\begin{array}{l}\text { MSP1041 - Health-Disease-Care } \\
\text { Process }\end{array}$ & $2^{\circ}$ & $\begin{array}{l}\text { Values / Ethics for Interprofessional Practice, } \\
\text { Roles / Responsibilities, Interprofessional } \\
\text { Communication, Teams and Work Teams }\end{array}$ \\
\hline Dentistry & $\begin{array}{l}\text { HSP0284 - Public Health Practice } \\
\text { Occupational Therapy }\end{array}$ & $\begin{array}{l}\text { MFT0715-Health Policy and } \\
\text { Rehabilitation in Brazil }\end{array}$ & $\begin{array}{l}\text { Values / Ethics for Interprofessional Practice, } \\
\text { Roles / Responsibilities, Interprofessional } \\
\text { Communication, Teams and Work Teams }\end{array}$ \\
\hline
\end{tabular}

\section{CONCLUSIONS}

Comparison with the guiding concepts of health promotion as well as the HPAC Guideline-recommended IPE strategies shows opportunities for dialogue on current initiatives with the international movement. However, in USP's health courses, although we have a recent and constant process of adapting the courses to the international movement of insertion of the guiding concepts in the curricula of the analyzed courses, the use of Interprofessional Education as a tool to improve professional education. of health is quite incipient. Thus, we can say that there is an educational field in which there is a need for investment, as such action would result in professionals better prepared to work in an interprofessional environment.

\section{REFERÊNCIAS}

1. Brasil. Ministério da Saúde. Secretaria de Vigilância em Saúde. Secretaria de Atenção à Saúde. Política Nacional de Promoção da Saúde: PNPS: revisão da Portaria MS/GM n ${ }^{\circ}$ 687, de 30 de março de 2006. Brasília: Ministério da Saúde, 2015 [citado 31 mar. 2018]. Disponível em: http://bvsms. saude.gov.br/bvs/publicacoes/pnps_revisao_portaria_687.pdf.

2. Brasil. Ministério da Saúde. Secretaria de Políticas de Saúde. Projeto Promoção da Saúde. As Cartas da Promoção da Saúde. Brasília: Ministério da Saúde; 2002 [citado 31 mar. 2018]. Disponível em: http://bvsms.saude.gov.br/bvs/publicacoes/ cartas_promocao.pdf.

3. Brinhosa MC. Interdisciplinaridade: possibilidades e equívocos. Acta Fisiátrica. 1998;5(3):164-9. Disponível em: https://s3-sa-east-1.amazonaws.com/publisher.gn1.com.br/
Knowing that collaborative practice, interprofessional education and excellent care are closely linked, promoting IPE, not only during the training of future professionals, but in the training of already active professionals could lead to an important improvement of our health system. However, such action still faces several challenges and barriers to be overcome, so USP, which is considered one of the largest universities in the country, should incorporate into its curriculum health courses such tools providing a learning environment that enables the formation professionals better prepared to work in multiprofessional teams, thus achieving a more integral and effective care

actafisiatrica.org.br/pdf/v5n3a04.pdf

4. Organização Mundial da Saúde (OMS). Marco para a ação na educação interprofissional e práticas colaborativas. 2012. Disponível em: http://new.paho.org/bra/images/stories/ documentos/marco_para_acao.pdf\%.

5. Health Professions Accreditors Collaborative. Guidance on developing quality interprofessional education for the health professions. Chicago, IL: Health Professions Accreditors Collaborative; 2019 [cited 2019 April 19]. Available from: https://healthprofessionsaccreditors.org/wp-content/ uploads/2019/02/HPACGuidance02-01-19.pdf

6. Okanagan Charter: an International Charter for Health Promoting Universities and Colleges. Kelowna, British 
Columbia, CA; 2015. Available from: http://www. healthpromotingcampuses.ca/wp-content/uploads/2016/11/ Okanagan-Charter-January13v2.pdf.

7. Brasil. Conselho Nacional de Educação. Câmara de Educação Superior Resolução n.3 de 20 junho de 2014. Institui as Diretrizes Curriculares Nacionais do curso de graduação em medicina. Brasília; 2014 [citado 19 abr. 2019]. Disponível em: http://portal.mec.gov.br/cne/arquivos/pdf/Med.pdf.

8. Tusset D. Competências em promoção da saúde no Programa Saúde na Escola no Distrito Federal [dissertação]. Brasília, DF: Universidade de Brasília - UnB, Faculdade de Educação Física; 2012. Disponível em: https://repositorio.unb.br/ handle/10482/11930.

9. Porter C. Ottawa to Bangkok: changing health promotion discourse. Health Promot Int. 2007;22(1):72-9. doi: 10.1093/ heapro/dal037.

10. Tesouros A, Dowding G, Thompson J, Dooris M, World Health Organization. Regional Office for Europe. (1998)?" Health promoting universities: concept, experience and framework for action. Copenhagen: WHO Regional Office for Europe; 1998. Available from: http://www.who.int/iris/ handle/10665/108095

11. Dempsey C, Barry M, Battel-Kirk B. The CompHP Core Competencies Framework for Health Promotion Handbook. Paris, France: IUHPE; 2011. Available from: http://www.szu. cz/uploads/documents/czzp/nerovnosti/2011/5.CompHP Core_Competencies_Framework_for_Health_Promotion_-

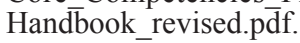

12. Gil AC. Métodos e técnicas de pesquisa social. 6a ed. São Paulo: Atlas; 2008.

13. Projeto Político Pedagógico do Curso de Educação Física e Esporte [citado 19 abr. 2019]. Disponível em: https:// uspdigital.usp.br/jupiterweb/jupCarreira.jsp? codmnu=8275

14. Projeto Político Pedagógico do Curso de Enfermagem [citado 19 abr. 2019]. Disponível em: https://uspdigital.usp. br/jupiterweb/jupCarreira.jsp? codmnu=8275.

15. Projeto Político Pedagógico do Curso de Fisoterapia [citado 19 abr. 2019]. Disponível em: https://uspdigital.usp.br/ jupiterweb/jupCarreira.jsp? codmnu $=8275$

16. Projeto Político Pedagógico do Curso de Fonoaudiologia [citado 19 abr. 2019]. Disponível em: https://uspdigital.usp. br/jupiterweb/jupCarreira.jsp?codmnu=8275.

17. Projeto Político Pedagógico do Curso de Medicina [citado 19 abr. 2019]. Disponível em: https://uspdigital.usp.br/ jupiterweb/jupCarreira.jsp? codmnu $=8275$.

18. Projeto Político Pedagógico do Curso de Nutrição [citado 19 abr. 2019]. Disponível em: https://uspdigital.usp.br/ jupiterweb/jupCarreira.jsp?codmnu $=8275$.

19. Projeto Político Pedagógico do Curso de Odontologia [citado 19 abr. 2019]. Disponível em: https://uspdigital.usp.br/ jupiterweb/jupCarreira.jsp?codmnu=8275.

20. Projeto Político Pedagógico do Curso de Terapia Ocupacional [citado 19 abr. 2019]. Disponível em: https://uspdigital.usp. br/jupiterweb/jupCarreira.jsp?codmnu= 8275 .

\section{BIBLIOGRAFIA COMPLEMENTAR}

1. Alves-Mazzotti AJ. O debate atual sobre os paradigmas de pesquisa em educação. Cad Pesqui (Fundação Carlos Chagas). 1996(96):15-23.

2. Kivunja C, Kuyini AB. Understanding and applying research paradigms in educational contexts. Int J High Educ. 2017;6:26-41. Available from: https://files.eric.ed.gov/ fulltext/EJ1154775.pdf.
3. Lüdke M, André MEDA. Pesquisa em educação: abordagens qualitativas. 2a ed. Rio de Janeiro: E.P.U.; 2018.

4. Brasil. Ministério da Saúde. Conselho Nacional de Saúde. Resolução n ${ }^{\circ} 510$, de 7 de abril de 2016. Diário Oficial da República Federativa do Brasil, Brasília, DF, 24 maio 2016. Seção 1. p.44-46 [citado 31 mar. 2018]. Disponível em: http:// conselho. saude.gov.br/resolucoes/2016/Reso510.pdf.

5. Frank E. Physician health and patient care. JAMA. 2004;291(5):637. doi: 10.1001/jama.291.5.637.

6. Florindo AA, Brownson RS, Mielke GI, Gomes GAO, Parra DC, Siqueira FV, Lobelo F, Simoes EJ, Ramos LR, Bracco MM, Hallal PC. Association of knowledge, preventive counseling and personal health behaviors on physical activity and consumption of fruits or vegetables in community health workers. BMC Public Health. 2015;15:344. doi: 10.1186/ s12889-015-1643-3.

7. Alba LH, Badoui N, Gil F. Attitude toward preventive counseling and healthy practices among medical students at a Colombian university. Front Med. 2015;9(2):251-9. doi: 10.1007/s11684-015-0393-z.

8. Yu Y, Li YYZ, Zhou B, Zhao Y, Yuan S, Zhang R, Sebranek M, Veerman L, Li M, Gong E, Chen S, Ma W, Huang L, Cho KW, Leeder S, Yan L. The association between medical students' lifestyles and their attitudes towards preventive counseling in different countries. BMC Public Health. 2015;15:1124. doi: 10.1186/s12889-015-2458-y.

9. Frank E, Hertzberg V. A Quantitative assessment of a 4-year intervention that improved patient counseling through improving medical student health. Med Gen Med. 2007;9(2):58. Available from: https://www.ncbi.nlm.nih.gov/ pmc/articles/PMC1994883/.

10. Schlair S, Hanley K, Gillespie C, Disney L, Kalet A, Darby PC, Frank E, Spencer E, Harris J, Jay M. How medical students' behaviors and attitudes affect the impact of a brief curriculum on nutrition counseling. J Nutr Educ Behav. 2012;44(6):653-7. doi: 10.1016/j.jneb.2011.08.006.

11. Lawlis T, Rechael AJ, Greenfield D. Barriers and enablers that influence sustainable interprofissional education: a literature review. J Interprof Care. 2014;28(4):305-10. doi: 10.3109/13561820.2014.895977.

12. Paradis E, Whitehead C. Louder than words: power and conflict in interprofessional education articles, 1954-2013. Med Educ. 2015;49(4):399-407. doi: 10.1111/medu.12668.

13. Frank E, Hedgecock J, Elon LK. Personal health promotion at US medical schools: a quantitative study and qualitative description of deans' and students' perceptions. BMC Med Educ. 2004;4(1):29. doi: 10.1186/1472-6920-4-29.

14. Potvin L, Jones C. Twenty-five years after the Ottawa Charter: the critical role of health promotion for public health. Can J Public Health. 2011;102(4):244-48.

15. Brasil. Câmara de Educação Superior. Conselho Nacional de Educação. Resolução CNE/CES n 3 de 7 de nov. de 2001. Institui as Diretrizes Curriculares Nacionais do curso de graduação em enfermagem. Disponível em: http://http:// portal.mec.gov.br/cne/arquivos/pdf/CES03.pdf

16. Newton J, Dooris M, Wills J. Healthy universities: an example of a whole-system health-promoting setting. Glob Health Promot. 2016;23(Suppl 1):57-65. doi: $10.1177 / 1757975915601037$

Received: November 22, 2019

Accepted: November 27, 2019 